\title{
Nedocromil Sodium Inhibits Hypertonic Saline-induced Plasma Extravasation in Guinea Pig Airways
}

\author{
Mika Ono, Toshio Abe, Makoto Watanabe, Yumi Yamada, Shigemi Yoshihara \\ Department of Pediatrics, Dokkyo University School of Medicine, Tochigi, 321-0293, JAPAN \\ (Received 14 September 1999; and accepted 30 September 1999)
}

\begin{abstract}
We investigated the potential of nedocromil sodium (NS) to reduce neurogenic plasma extravasation induced by hypertonic saline in guinea pig airways. Plasma extravasation was assessed by photometric measurement of extravasated Evans blue after formamide extraction. Hypertonic saline was delivered to anesthetized, artificially ventilated guinea pigs through a tracheal cannula. Inhalation of hypertonic saline for 2 min increased Evans blue dye extravasation in the trachea in a concentration-dependent $(0.9,5,10,15$ and $20 \%)$ manner. The increase in plasma extravasation induced by hypertonic saline (15\%) was significantly reduced by pretreatment with NS $(10 \mathrm{mg} / \mathrm{kg}, i . v$. $)$. The inhibition of plasma extravasation by NS $(10 \mathrm{mg} / \mathrm{kg}, i$. v.) alone was not different from the inhibition induced by the combination of NS and the bradykinin $\mathrm{B}_{2}$ receptor antagonist, HOEI40 $(0.1 \mu \mathrm{mol} / \mathrm{kg}, i$. v. $)$ or HOEI40 $(0.1 \mu \mathrm{mol} / \mathrm{kg}, i$. v. $)$ alone. However, pretreatment with the combination of NS $(10 \mathrm{mg} / \mathrm{kg}, i$. v.) and the tachykinin $\mathrm{NK}_{1}$ and $\mathrm{NK}_{2}$ receptor antagonist, FK $224(3.2 \mathrm{mg} / \mathrm{kg}, i$. v. $)$ abolished the increase in plasma extravasation induced by hypertonic saline (15\%). The increase in plasma extravasation induced by inhalation of bradykinin $(0.1 \mathrm{mM})$ for 2 min was abolished by pretreatment with $\mathrm{NS}(10 \mathrm{mg} / \mathrm{kg}, i$ v. $)$. These findings suggest that NS reduced the hypertonic saline-induced plasma extravasation by inhibiting bradykinin-dependent neurogenic inflammation in guinea pig airways.
\end{abstract}

The inhalation of aerosols of hypertonic saline causes airways to narrow in the majority of patients with symptoms of asthma (20). The stimulus causing the airways to narrow is thought to be an increase in the osmolarity of the periciliary fluid, thus providing a favorable environment for mast cell release of histamine and other mediators. In most asthmatic subjects the airway response to hypertonic saline can be reduced, and in some cases inhibited, by medication with antihistamines given either orally or by aerosol (19). In addition to mast cell release of mediators, the possibility exists that increases in osmolarity

Correspondence to: Dr Shigemi Yoshihara at the above address.

Tel: 81-282-87-2155 Fax: 81-282-86-7521 cause narrowing of the airways by the release of tachykinins from sensory nerves. Although there is no evidence from humans to support this, recent studies in rats have demonstrated increases in vascular permeability directly related to changes in osmolarity that are prevented by treatment with capsaicin (21). Furthermore, recent studies of human lung tissue in vitro support a role for mast cell release of mediators and release of tachykinins in the presence of hyperosmolarity (8).

Nedocromil sodium (NS) is a disodium salt of a pyranoquinoline dicarboxylic acid (17). It inhibits the in vitro release of inflammatory mediators from sensitized human lung mast cells $(11,12)$ and a range of inflammatory cells, including eosinophils, neutrophils, monocytes, macro- 
phages, and platelets (17). It is also effective in producing a dose-dependent inhibition of histamine release from mast cells obtained from lung fragments and bronchoalveolar lavage fluid in both normal and asthmatic subjects $(11,12)$. When NS is inhaled by asthmatic subjects, it inhibits airway narrowing caused by antigens (22), cold air (5), distilled water aerosol (18), hypertonic saline (10), exercise (9), and substance $P(4)$. These challenges are thought to provoke narrowing of the airways by the release of chemical mediators. In addition, NS is effective against bronchoconstriction induced by challenge with bradykinins (6) and tachykinins (4). Some of these challenges are thought to narrow the airways via a parasympathetic reflex, but neurogenic inflammation by the release of tachykinins from sensory nerves may also be important $(1,2)$. As an increase in airway osmolarity is likely to involve both release of mediators from mast cells and neuropeptides from sensory nerves, it would be expected that NS would attenuate the airway inflammation to a hypertonic challenge.

Bradykinin may cause inflammation by a direct action on bradykinin receptors or effector cells, or via indirect mechanisms. For instance, part of the inflammatory response produced by locally applied bradykinin in certain tissues, such as airways, is due to stimulation of the release of neuropeptides, including tachykinins, from peripheral endings of primary sensory nerves (7). In the present study, we examined the question of whether NS inhibits plasma extravasation in response to hypertonic saline in guinea pig airways. Furthermore, we investigated whether NS inhibits bradykinin-dependent neurogenic inflammation induced by hypertonic saline using a recently developed tachykinin $\mathrm{NK}_{1}$ and $\mathrm{NK}_{2}$ receptor antagonist, FK224, bradykinin $\mathrm{B}_{2}$ receptor antagonist, HOE140, the combination of NS and HOE 140 and the combination of NS and FK224.

\section{MATERIALS AND METHODS}

\section{Animals}

Male Hartley guinea pigs (Japan SLC, Inc.) weighing 300-500 $\mathrm{g}$ at the time of housing, were used in this study. They were kept in a temperature-controlled environment with standard laboratory food and water freely available.

\section{Exposure to hypertonic saline}

On the day of the experiment, the animals (300$500 \mathrm{~g})$ were anesthetized with sodium pentobarbital $(50 \mathrm{mg} / \mathrm{kg}, i . p$. ). A midline cervical incision was made to expose the larynx and upper trachea. The trachea was incised immediately below the larynx, and a cannula was inserted $4 \mathrm{~mm}$ into the trachea. The animals were then artificially ventilated at a frequency of 70 breaths/min with a tidal volume of $6 \mathrm{~mL}(3,23)$ using a constant volume ventilator (Rodent Ventilator Model 683, Harvard Apparatus, Millis, MA, U.S.A.). Hypertonic saline $(5 \%, 10 \%, 15 \%$ and $20 \%)$, bradykinin $(0.1 \mathrm{mM})$ or vehicle alone was delivered to animals for 2 min via the tracheal cannula, using an ultrasonic nebuliser, (Pulmo-Sonic model 25, De Vilbiss Co., Somerset, PA; aerosol delivery rate $0.2 \mathrm{~mL} / \mathrm{min}$ ).

\section{Experimental procedure}

Vascular extravasation was quantified by injection of Evans blue dye (3\% solution in $0.9 \%$ $\mathrm{NaCl} ; 30 \mathrm{mg} / \mathrm{kg}, i . v$. over $5 \mathrm{~s}$ ) at the beginning of each test. At the end of the experiment, the chest was opened, the aorta was cannulated through the left ventricle, and the circulation was perfused for 3 min with a phosphate buffer of $\mathrm{pH} 5$ at a pressure of $120 \mathrm{mmHg}$. The trachea was dissected and opened along the ventral midline, from the first cartilaginous ring to the carina, blotted on absorbent paper, and weighed. Tissues were incubated in $3 \mathrm{~mL}$ formamide at $50^{\circ} \mathrm{C}$ for $18 \mathrm{~h}$ to extract the extravasated Evans blue dye (13). In experiments in which hypertonic saline (15\%) was used, vascular perfusion was performed following $10 \mathrm{~min}$ of exposure. To obtain a baseline value for Evans blue dye extravasation, saline was delivered for periods identical to those for hypertonic saline. NS ( $10 \mathrm{mg} / \mathrm{kg}, i$ v. $)(1)$, disodium cromoglycate (DSCG; $10 \mathrm{mg} / \mathrm{kg}, i . \quad$ v.) (6) or tachykinin $\mathrm{NK}_{1}$ and $\mathrm{NK}_{2}$ receptor antagonist FK224, $(3.2 \mathrm{mg} / \mathrm{kg}, \quad$ i. v. $)(14,15)$ was injected 5 min before the inhalation of hypertonic saline $(15 \%)$ or bradykinin $(0.1 \mathrm{mM})(3,25)$. Hypertonic saline $(15 \%)$, bradykinin $(0.1 \mathrm{mM})$ or vehicle was delivered to animals for 2 min via the tracheal cannula, using an ultrasonic nebuliser (Pulmo-Sonic model 25, De Vilbiss Co., Somerset, PA; aerosol delivery rate $0.2 \mathrm{~mL} / \mathrm{min}$ ). Bradykinin $B_{2}$ receptor antagonist $\operatorname{HOE} 140(0.1 \mu \mathrm{mol} /$ $\mathrm{kg}, i$. v. $)(3,24)$ or vehicle was injected $10 \mathrm{~min}$ 
before the inhalation of hypertonic saline. Phosphoramidon $(2.5 \mathrm{mg} / \mathrm{kg}, i$ v. $)(3,26)$ was injected 5 min before the inhalation of bradykinin $(0.1$ $\mathrm{mM}$ ). NS was dissolved in saline, and HOE 140 and bradykinin were delivered in distilled water. FK224 was dissolved in dimethylsulfoxide.

\section{Measurement of plasma extravasation}

Extravasation of the dye-labelled macromolecules was assessed by measuring the optical density of the formamide extracts at a wavelength of $620 \mathrm{~nm}$ with a spectrophotometer (model 220A, Hitachi, Japan). The amount of Evans blue dye extravasated from the tissue, expressed as ng/mg wet weight, was interpolated from a standard curve of Evans blue dye concentrations.

\section{Drugs}

Hypertonic saline $(5 \%, 10 \%, 15 \%$ and $20 \%)$ was made from $\mathrm{NaCl}$ (Wako Pure Chemical Industries Ltd., Osaka, Japan) solution in $0.9 \% \mathrm{NaCl}$. Evans blue dye and DMSO were obtained from Sigma Chemical Co. (St. Louis, MO). Bradykinin and HOE140 were purchased from Peptide Institute Inc. (Osaka, Japan). NS was kindly provided by Dr. A.Norris (Roohne-Poulenc Rorer). FK224 and DSCG were supplied from Fujisawa Pharmaceutical Co. Ltd. (Tokyo, Japan).

\section{Statistical analysis}

All data were expressed as mean \pm S. E. M. Statistical comparisons were performed using a one-way analysis of variance, and Dunnett's test or a bilateral unpaired Student's $t$ test, when appropriate. In all cases, differences at a $P$ value of less than 0.05 were considered significant.

\section{RESULTS}

Plasma extravasation induced by hypertonic saline

Exposure of guinea pig airways to $0.9 \% \mathrm{NaCl}$ produced an extravasation of Evans blue dye of $23.8 \pm 3.45 \mathrm{ng} / \mathrm{mg}(\mathrm{n}=5)$. Exposure to hypertonic saline produced a concentration-dependent increase in tracheal plasma extravasation $(5 \%$, $70.6 \pm 5.8 \mathrm{ng} / \mathrm{mg} ; 10 \%, 96.8 \pm 6.6 \mathrm{ng} / \mathrm{mg} ; \quad 15 \%$, $115.0 \pm 18.7 \mathrm{ng} / \mathrm{mg} ; 20 \%, 126.0 \pm 12.9 \mathrm{ng} / \mathrm{mg} ; \mathrm{n}=$ 5; Fig. 1).
Effect of nedocromil sodium on hypertonic saline -induced plasma extravasation

Inhalation of $15 \%$ hypertonic saline for $2 \mathrm{~min}$ significantly increased the extravasation of the Evans blue dye in the trachea $(126.2 \pm 12.5 \mathrm{ng} /$ $\mathrm{mg} ; \mathrm{n}=5)$. Pretreatment with DSCG $(10 \mathrm{mg} / \mathrm{kg}, i$. $v$; $90.1 \pm 7.32 \mathrm{ng} / \mathrm{mg} ; \mathrm{n}=5$ ) significantly reduced the hypertonic saline-induced plasma extravasation in the trachea. Pretreatment with NS $(10 \mathrm{mg} /$ $\mathrm{kg}, \quad$ i. $\quad v_{;} ; 70.7 \pm 3.3 \mathrm{ng} / \mathrm{mg} ; \quad \mathrm{n}=5$ ) significantly reduced the plasma extravasation compared with DSCG. The inhibition of the response to hypertonic saline (15\%) produced by the combination of NS $(10 \mathrm{mg} / \mathrm{kg}, i$. v. $)$ and $\mathrm{B}_{2}$ receptor antagonist, HOE $140(0.1 \mu \mathrm{mol} / \mathrm{kg}, i . \quad v ; 63.4 \pm 4.1 \mathrm{ng} /$ $\mathrm{mg} ; \mathrm{n}=5$ ) was not significantly different from the response obtained with $\mathrm{NS}(10 \mathrm{mg} / \mathrm{kg}, i$. HOEI $40(0.1 \mu \mathrm{mol} / \mathrm{kg}, i . v ; ; 67.3 \pm 4.2 \mathrm{ng} / \mathrm{mg} ; \mathrm{n}=$ 5) alone. However, pretreatment with the combination of NS $(10 \mathrm{mg} / \mathrm{kg}, i$. v.) and FK224 (3.2 $\mathrm{mg} / \mathrm{kg}, i$. v) abolished the plasma extravasation of the Evans blue dye induced by hypertonic saline( $15 \%)$ for $2 \mathrm{~min}$ in the trachea $(33.9 \pm 6.3$ $\mathrm{ng} / \mathrm{mg} ; \mathrm{n}=5)$. Pretreatment with FK224 (3.2mg/ $\mathrm{kg}, i$. v.) alone also abolished the increase of plasma extravasation induced by hypertonic saline (data not shown) (Fig. 2).

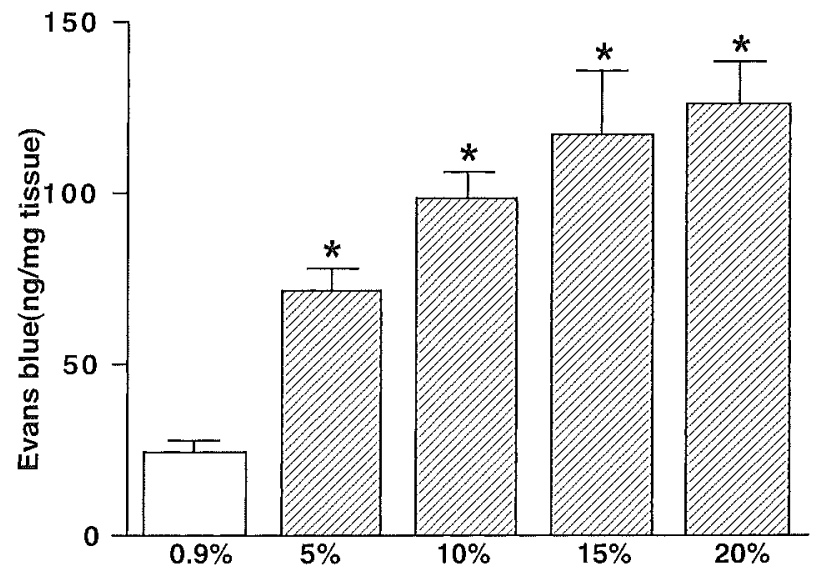

Fig. 1 Effect of exposure to different consentration of hypertonic saline $(5,10,15$ and $20 \%)$ on the extravasation of Evans blue dye in the trachea of pentobarbital anesthetized guinea pigs. Plasma extravasation was evaluated by measuring the amount of Evans blue dye extravasated in the trachea after $10 \mathrm{~min}$. Values are means $\pm \mathrm{S}$. E. M.; $\mathrm{n}=5$ per group. ${ }^{*} P<0.05$ versus control $(0.9 \%$ saline $)$ in trachea. 
Effect of nedocromil sodium on bradykinininduced plasma extravasation

The extravasation of Evans blue dye in the trachea of the guinea pig after exposure to the aerosolised vehicle of bradykinin in the presence of phosphoramidon $(2.5 \mathrm{mg} / \mathrm{kg}, i$. significantly different from the baseline $(33.3 \pm 5.8$ $\mathrm{ng} / \mathrm{mg} ; \mathrm{n}=5$ ). Inhalation of $0.1 \mathrm{mM}$ bradykinin for $2 \mathrm{~min}$ in the presence of phosphoramidon $(2.5 \mathrm{mg} / \mathrm{kg}, \quad i$. v.) significantly increased the extravasation of the Evans blue dye in the trachea $(97.9 \pm 4.9 \mathrm{ng} / \mathrm{mg} ; \mathrm{n}=5)$. The bradykinininduced plasma extravasation was abolished completely by NS $(10 \mathrm{mg} / \mathrm{kg}, i$. v.) $5 \mathrm{~min}$ before aerosol challenge in the trachea $(38.9 \pm 3.4 \mathrm{ng} / \mathrm{mg} ; \mathrm{n}=5)$ (Fig. 3).

\section{DISCUSSION}

The major finding of the present study was that NS inhibits hypertonic saline-induced plasma extravasation, an effect caused by activation of sensory nerves induced by bradykinin, and the

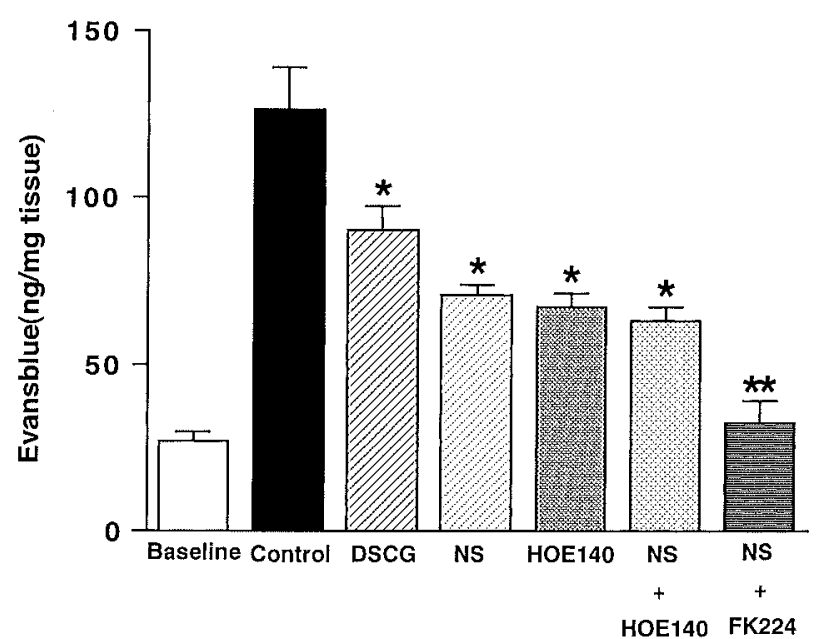

Fig. 2 Effect of nedocromil sodium (NS; $10 \mathrm{mg} / \mathrm{kg}$, i. v.), disodium cromoglycate (DSCG; $10 \mathrm{mg} / \mathrm{kg}, i$. v.), HOE $140(0.1 \mu \mathrm{mol} / \mathrm{kg}, i . v$. $)$, combination of NS $(10 \mathrm{mg} / \mathrm{kg}, i$. v.) and HOE $140(0.1 \mu \mathrm{mol} / \mathrm{kg}, i$. v. $)$ or combination of NS $(10 \mathrm{mg} / \mathrm{kg}, i$. v.) and FK224 $(3.2 \mathrm{mg} / \mathrm{kg}, \quad i . v$.) on Evans blue extravasation in guinea pig trachea induced by inhalation of hypertonic saline (15\%, $2 \mathrm{~min}$ ). Plasma extravasation was evaluated by measuring the amount of Evans blue dye extravasated in the trachea after $10 \mathrm{~min}$. Values are means \pm S. E. M.; $\mathrm{n}=5$ per group. ${ }^{*} P<0.05$ versus control in trachea. ${ }^{*} P<0.05$ versus NS ( 10 $\mathrm{mg} / \mathrm{kg}, i$. v.) in trachea. subsequent release of tachykinins in the guinea pig trachea.

The inhalation of aerosols of hypertonic saline is thought to mediate airway narrowing, in part by the release of mast cell mediators. Evidence in rats suggests that hyperosmolarity may also increase vascular permeability by a mechanism involving sensory neuropeptides. The tachykinin receptor antagonist, CP99, 994, produces stereoselective inhibition of neurogenic plasma extravasation induced by inhalation of hypertonic saline in the rat trachea (16). NS has been shown to be capable of inhibiting chloride ion flux in mast cells, epithelial cells, and neurons (11). NS inhibits antigen-induced plasma extravasation at all airway levals in the guinea pig. Since NS alone had only a small effect on plasma extravasation induced directly by histamine and platelet activation factor, its effect is probably due to inhibition of mediator release from inflammatory cells (1). NS may have effects on sensory nerve endings, which may be an important site of action in the reduction of neurogenic inflammation in airways. NS has been found to be at least one order of magnitude more potent than DSCG in suppressing histamine release from mast cells $(11,12)$.

In the present study, hypertonic saline-induced

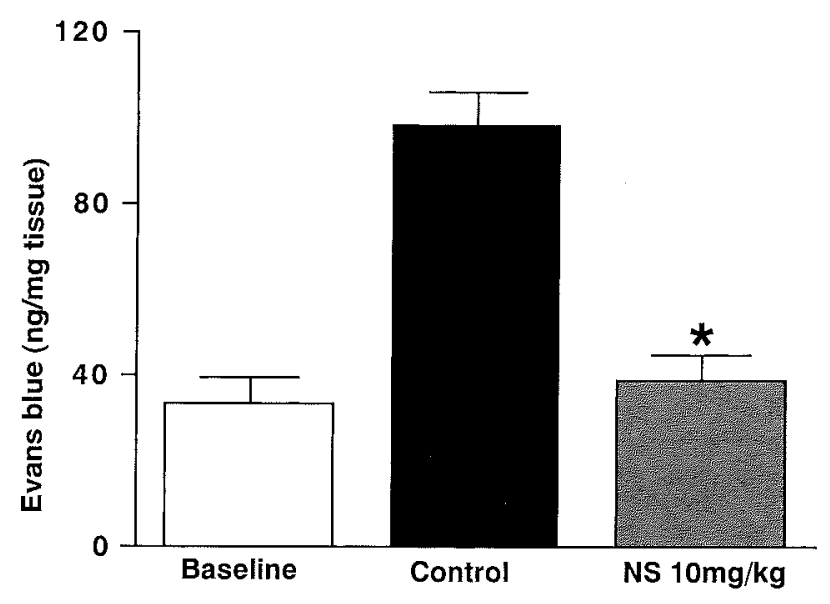

Fig. 3 Effect of nedocromil sodium (NS; $10 \mathrm{mg} / \mathrm{kg}$, $i$. v.) on Evans blue extravasation in guinea pig trachea induced by inhalation of bradykinin $(0.1$ $\mathrm{mM}, 2 \mathrm{~min})$ in presence of phosphoramidon $(2.5 \mathrm{mg}$ / $\mathrm{kg}, i . v,, 5 \mathrm{~min}$ before exposure). Plasma extravasation was evaluated by measuring the amount of Evans blue dye extravasated in the trachea after 10 min. Values are means \pm S. E. M.; $n=5$ per group. ${ }^{*} P<0.05$ versus control (Inhalation of bradykinin in presence of phosphoramidon) in trachea. 
plasma extravasation was concentrationdependent. Pretreatment with NS inhibited the increase of hypertonic saline (submaximal dose; $15 \%$ )-induced plasma extravasation. NS significantly reduced the hypertonic saline-induced plasma extravasation compared with DSCG in the guinea pig trachea. The inhibition of the response to hypertonic saline produced by NS was not significantly different from the response obtained with the combination of NS and bradykinin $\mathrm{B}_{2}$ receptor antagonist, $\mathrm{HOE} 140$, or HOE140 alone. In these result, NS inhibited the increase of plasma extravasation induced by bradykinin. Furthermore, pretreatment with NS 5 min before aerosol challenge abolished the bradykinin-induced plasma extravasation in the guinea pig trachea. In these study, NS significantly inhibited hypertonic saline-induced plasma extravasation, an effect caused by activation of sensory nerves induced by bradykinin.

Ovalbumin-induced plasma extravasation was significantly reduced by the bradykinin $\mathrm{B}_{2}$ receptor antagonist, HOE140 (3) or FR173657 (26), in the sensitized guinea pig. The combination of the tachykinin $\mathrm{NK}_{1}$ receptor antagonist CP96,345 and HOE140 did not further increase the inhibition obtained with CP96,345 alone. These results provide evidence that the activation of sensory nerves that contribute to antigen-induced plasma extravasation is due to kinin release $(3,24)$. However, cigarette smoke-induced plasma extravasation is inhibited by the tachykinin $\mathrm{NK}_{1}$ receptor antagonist, CP99,994, but not HOE140 (25). It has been reported that the involvement of kinin-dependent neurogenic inflammation differes according to the stimulus. In the present study, pretreatment with the combination of NS and tachykinin $\mathrm{NK}_{1}+\mathrm{NK}_{2}$ receptor antagonist, FK224, abolished the increase of plasma extravasation induced by hypertonic saline. FK224 alone also abolished the increase of plasma extravasation. However NS partially inhibited the plasma extravasation. In these results, the increase of hypertonic saline-induced plasma extravasation involve the release of tachykinin from sensory nerves both directly and indirectly (sensory nerve activated by bradykinin). At least, in this hypertonic saline study, NS inhibited the increase of plasma extravasation induced by tachykinin release from sensory nerves activated by bradykinin.

These findings suggest that NS significantly reduces hypertonic saline-induced plasma extravasation in the guinea pig trachea by inhibiting bradykinin-dependent neurogenic inflammation. If these findings are substantiated in human beings, NS may prove to be a useful therapeutic agent for the treatment of inflammatory airway diseases such as asthma.

\section{Acknowledgements}

We are very grateful to Prof. O. Arisaka M. D. providing us with much valuable advice and for reviewing this manuscript.

\section{REFERENCES}

1. Barnes P. J. (1989) Effect of Nedocromil Sodium on Airway Microvascular Leakage and Neural Reflexes. Drugs 37, 94-100.

2. Barnes P. J., MA, DM, DSc, FRCP. (1996)Neuroeffector machanisms: The interface between inflammation and neuronal responses. J. Allergy Clin. Immunol. 98, S73-83.

3. Bertrand C., Nadel J. A., Yamawaki I., Geppetti P. (1993) Role of Kinins in the Vasucular Extravasation Evoked by Antigen and Mediated by Tachykinins in Guinea Pig Trachea. J. Immunol. 151, 4,902.

4. Crimi N., Palermo F., Oliveri R., Palermo B., Vancheri C., Polosa R., Mistretta A. (1988) Effect of nedocromil on bronchocospasm induced by inhalation of substans $\mathrm{P}$ in asthmatic subjects. Clin. Allargy 18, 375-382.

5. Del Bono L., Dente F. L., Patalano F., Del Bono N. (1986) Protective effect of nedocromil sodium and sodium cromoglycate on bronchospasm induced by cold air. Eur: J. Respir: Dis. 69, (Suppl 147, 268-270).

6. Dixon C. M. S., Barnes P. J. (1989) Bradykinin-induced bronchoconstriction: inhibition by nedocromil sodium and sodium cromoglycate. Br.J. Clin. Pharmac. 27, 831836.

7. Geppetti P. (1993) Sensory neuropeptide release by bradykinin: mechanisms and pathophysiological implications. Regul. Pept. 47, 1-23.

8. Jongejan R. C., de Jongste J. C., Raatgeep H. C., Stijnen T., Bonta I. L., Kerrebijn K. F. (1991) Effect of hyperosmolarity on isolated central airways. $B r . J$. Pharmacol. 102, 931-937.

9. König P., Hordvik N. L., Kreutz C. (1987) The preventive effect and duration of action of nedocromil sodium and cromolyn sodium on exersise-induced asthma(EIA) in adults. J. Allergy Clin. Immunol. 79, 64-68.

10. Leanne T. Rodwell, Sandra D. Anderson, Jacqueline Du Toit, Paul Seale (1992) Nedocromil sodium inhibits the airway response to hyperosmolar challenge in patients with asthma. Am. Rev. Respir. Dis. 146, 1149-1155.

11. Leung K. B. P., Flint K. C., Brostoff J., Hundspith B. N., Johnson N. M., Pearce F. L. (1986) A comparison of nedocromil sodium and sodium cromoglycate on human lung mast cells obtained by bronchoalveolar lavage and by dispersion of lung fragments. Eur. J. Respir: Dis. 69, 223226.

12. Leung K. B. P., Flint K. C., Brostoff J., Hundspith B. N., Johnson N. M., Lau H. Y. A., Liu W. L., Pearce F. L. (1988) Effect of sodium cromoglycate and nedocromil 
sodium on histamine secretion from human lung mast cells. Thorax 43, 756-761.

13. Lundberg J. M., and Saria A. (1983) Capsaicin-induced desensitization of airway mucosa to cigarette smoke, mechanical and chemical irritants. Nature 302, 25I-253.

14. Murai M., Morimoto H., Maeda Y., Kiyotoh S., Nishikawa M., Fujii T. (1992) Effect of FK224, a Novel Compound $\mathrm{NK}_{1}$ and $\mathrm{NK}_{2}$ Receptor Antagonist, on Airway Constriction and Airway Edema Induced by Neurokinins and Sensory Nerve Stimulation in Guinea Pigs. J. Pharmacol. Exp. Ther: 262, 403 408.

15. Morimoto H., Murai M., Maeda Y., Yamaoka M., Nishikawa M., Kiyotoh S., Fujii T. (1992) FK224, A Novel Cyclopeptide Substance $\mathrm{P}$ Antagonist with $\mathrm{NK}_{1}$ and $\mathrm{NK}_{2}$ Receptor Selectivity. J. Pharmacol. Exp. Ther. 262, 398402.

16. Piedimonte G., Bertrand C., Geppetti P., Snider R. M., Desai M. C., Nadel J.A. (1993) A new $\mathrm{NK}_{1}$ receptor antagonist (CP-99, 994) prevents the increase in tracheal vascular permeability produced by hypertonic saline. $J$. Pharmacol. Exp. Ther: 266, 270-273.

17. Rainey D. K. (1989) Nedocromil sodium Tilade ${ }^{\text {Tat: a }}$ review of preclinical studies. Eur, Respir. J. 2, (Suppl 6: 561S-565).

18. Robuschi M., Vaghi A., Simone P., Bianco S. (1987) Prevention of fog-induced bronchospasm by nedocromil sodium. Clin. Allergy 17, 69-74.

19. Rodwell L. T., Anderson S. D., Seale J. P. (1991) Inhaled clemastine inhibits airway narrowing caused by aerosols of non-isotonic saline. Eur: Respir. J. 4, 1126-34.
20. Smith C. M., Anderson S. D. (1989) Inhalation provocation tests using nonisotonic aerosols. J. Allergy Clin. Immunol. 84, 781-90.

21. Umeno E., McDonald D. M, Nadel J. A.(1990) Hypertonic saline increases vascular permeability in the rat trachea by producing neurogenic inflammation. J. Clin. Invest. 85, 1905-1908.

22. Youngchaiyud P., Lee T. B. (1986) A double-blind, crossover trial comparing nedocromil sodium with placebo in bronchial antigen challenge tests. Eur. J. Respir. Dis. 69, (Supple 147, 302-304).

23. Yoshihara S., Chan B., Yamawaki I., Geppetti P., Riccardolo F. L. M., Massion P., Nedel J. A. (1995) Plasma Extravasation in the Rat Trachea Induced by Cold Air Is Mediated by Tachykinin Release from Sensory Nerves. Am. J. Respir. Crit. Care Med. 151, 1011-1017.

24. Yoshihara S., Riccardolo F. L. M., Geppetti P., Linden A., Hara M., Chan B.,Nedel J. A. (1995) Corticotropinreleasing factor inhibits antigen-induced plasma extravasation in airways. Eur. J. Pharmacol. 280 113-118.

25. Watanabe M., Yoshihara S., Fukuda N., Ono M., Arisaka O. (1998) Cigarette smoke-induced plasma extravasation is inhibited by CP99, 994, but not HOE140. Biomed. Res. 19 , 309-314.

26. Watanabe M., Yoshihara S., Abe T., Oyama M., Arisaka O. (1999) Effects of orally active non-peptide bradykinin $B_{2}$ receptor antagonist, FR173657, on plasma extravasation in guinea pig airways. Eltr. J. Phamacol. $367,373-378$. 